\title{
Role of Autophagy in Preeclampsia
}

\author{
Nurrani M. Dewi ${ }^{1,2}$, Rina Triana ${ }^{1,2}$, Angliana Chouw ${ }^{1,3}$, Siska Darmayanti ${ }^{1,2}$ \\ ${ }^{1}$ Faculty of Pharmacy, Universitas Padjadjaran, Bandung, Indonesia, ${ }^{2}$ Prodia Clinical \\ Laboratories, Jakarta, Indonesia, ${ }^{3}$ Prodia Stemcell Indonesia, Jakarta, Indonesia
}

\begin{abstract}
Autophagy is essential in cell death decisions and can protect cells by preventing them from undergoing apoptosis. Autophagy contributes to a variety of physiological processes, including cell differentiation and various functions in embryogenesis. Some studies reported that the expressions of autophagy-related (Atg) proteins are found in placentas. This review article was focusing on the autophagy process and some Atg proteins which are involved in human placentation, especially in preeclampsia cases, since it has been well known that abnormal placentation and placenta dysfunction has crucial role in its development. Preeclampsia cannot be related to a single cause and the underlying mechanism of it is still not clearly understood. Recent hypothesis regarding the cause of preeclampsia is more focused on the inadequate trophoblast invasion and placentation. Scientists also suggested that other mechanism might be associated with this condition in preeclampsia, which is autophagy. Autophagy is a mechanism that essential for cellular remodeling which occurs during the development of multicellular organisms in the special process, by expressing an "eat-me" signal and cleared by neighboring cells. In preeclampsia patients, autophagy has an important role in trophoblast function under physiologically low oxygen conditions. The activation of autophagy in preeclampsia is shown by the different level of abundance of key protein of the Atg pathway. Some Atg proteins known to be related to preeclampsia are Beclin-1, $\mathrm{LC} 3$, and $\mathrm{p} 62$.
\end{abstract}

Keywords: Atg proteins, cell death, embryogenesis, placentation

\section{Peran Autofagi dalam Preeklampsia}

\begin{abstract}
Abstrak
Autofagi memiliki peran yang penting dalam keputusan kematian sel dan dapat melindungi sel dengan cara mencegahnya mengalami apoptosis. Autofagi berkontribusi pada berbagai proses fisiologis, termasuk diferensiasi sel dan berbagai fungsi dalam embriogenesis. Beberapa penelitian melaporkan bahwa ekspresi protein Atg ditemukan di plasenta. Artikel review ini berfokus pada proses autofagi dan beberapa protein autophagy-related (Atg) yang terlibat dalam plasentasi, terutama pada kasus preeklampsia, karena telah diketahui bahwa plasentasi abnormal dan disfungsi plasenta memiliki peran yang penting dalam perkembangan. Preeklampsia tidak dapat dikaitkan dengan satu penyebab saja, dan mekanisme yang mendasarinya masih belum dipahami secara jelas. Hipotesis terbaru mengenai penyebab terjadinya preeklampsia lebih terfokus pada invasi trofoblast yang tidak memadai dan kesalahan plasentasi. Para ilmuwan juga menyarankan bahwa mekanisme lain yang mungkin terkait dengan kondisi ini adalah autofagi. Autofagi adalah mekanisme yang penting untuk pemodelan ulang seluler yang terjadi selama perkembangan organisme multiseluler dalam proses khusus, dengan mengekspresikan sinyal "makansaya" dan kemudian dibersihkan oleh sel tetangga. Pada pasien preeklampsia, autofagi memiliki peran penting dalam fungsi trofoblas di bawah kondisi oksigen rendah. Pengaktifan autofagi pada preeklampsia ditunjukkan oleh perbedaan tingkat kelimpahan protein utama dari pathway Atg. Beberapa protein Atg yang diketahui terkait dengan preeklampsia adalah Beclin-1, LC3, dan p62.
\end{abstract}

Kata kunci: Embriogenesis, kematian sel, plasentasi, protein Atg

Correspondence: apt. Nurrani M. Dewi, M.Farm., Faculty of Pharmacy, Universitas Padjadjaran, Bandung, West Java 40161, Indonesia, email: nurranimustika@gmail.com

Submitted: 22 ${ }^{\text {nd }}$ May 2017, Accepted: 29 ${ }^{\text {th }}$ December 2017, Published: 31 ${ }^{\text {st }}$ March 2020 


\section{Introduction}

Programmed cell death (PCD) is important to determine the fate of cell, since it is involved in different kind of biological events in human body. PCD dysfunction can cause various diseases in human. Over the past years, many scientists studied PCD from the molecular mechanism of apoptosis. However there is another form of PCD beside the well-known apoptosis, which is autophagy. Similar with apoptosis, autophagy also plays an important role in the development of the cell. ${ }^{1}$ Both apoptosis and autophagy are highly-controlled processes which have important roles in human development, tissue homeostasis and disease. ${ }^{2}$

Autophagy is essential in cell death decisions and can protect cells by preventing them from undergoing apoptosis, in which both mechanisms are very important in the physiology of normal and wide range of diseases. ${ }^{3}$ Autophagy is also highly active during differentiation and development, and it contributes to a variety of physiological processes, which includes cell differentiation and also various functions in embryogenesis. ${ }^{4}$ Moreover, autophagy is also important in the pre-implantation development process beyond four- and eight-cell stages and the survival of blastocyst. The activation of autophagy is shown by the increase of key proteins of the autophagy-related (Atg) pathway, for example Beclin-1 and microtubule-associated protein 1A/1B-light chain 3 (LC3). Previous studies reported that the expressions of Atg proteins are found in placentas. ${ }^{5,6}$

The process of autophagy can be seen in the development of placenta. In normal condition, autophagy plays important roles during nutritional deficiency at the early stage so that the neonates could survive. It also helps the trophoblast to release related cytokines in order to maintain the pregnancy. The expression of cytokine is the abnormal condition that might result in any gynecological disease, such as intra-uterine growth restriction and preeclampsia. There are different patterns during normal pregnancy and pregnancy with preeclampsia that is shown by the expression of Atg markers. ${ }^{7}$ This review article will focus on the autophagy process and some Atg proteins which are involved in human placentation, especially in preeclampsia cases, since it is well-known that abnormal placentation and placenta dysfunction has crucial role in its development.

\section{Methods}

A search for studies published in 2005-2017 was done in Pubmed and Google Scholar database using the search strategy, and the keywords used are autophagy, preeclampsia, pregnancy-induced hypertension, placental development, and Atg protein. The search was limited only to studies published in the English language. In this article, we discuss autophagy process associated with the pathogenesis of preeclampsia, in which autophagy takes an important role in sustaining cell health by maintaining the balance of cells.

\section{Mechanism of Autophagy}

Autophagy, or also known as self-eating, is a process of intracellular degradation of cellular component which is accountable for lysosomal degradation of protein and other subcellular constituents. ${ }^{2,6}$ Autophagy is a system by which cytoplasmic components, including macromolecules (e.g., proteins, lipids and nucleotides) and organelles (e.g., mitochondria, peroxisome and endoplasmic reticulum) are through a degradation process into small molecules that are then recycled by the lysosome. ${ }^{4}$ The authors agree that the mechanism of autophagy is important in maintaining the balance of cell recycling and cellular changes, such as in the condition of nutritional deprivation or intracellular stress, 
autophagy is often activated to maintain the cellular homeostasis. ${ }^{2,6}$ That is why autophagy is crucial for the cellular response to starvation and stress. ${ }^{5}$ The stress which caused the antiapoptotic protein complex will be released so that the autophagy process occurs, where Atg might play a role in membrane dynamics and maintain the balance of cell survival and apoptosis.

\section{Autophagy in the Placenta of Preeclampsia Patient}

Maternal hypertensive disorders are the most common causes of maternal, fetal and neonatal mortality worldwide, in which one of them is preeclampsia. Preeclampsia is characterized by the elevated blood pressure (greater than $140 / 90 \mathrm{mmHg}$ ) combined with generalized edema and/or proteinuria after 20 weeks of gestation. $^{6,8}$ This condition was known to evolve during early pregnancy and manifest as endothelial or vascular dysfunction. ${ }^{9}$

Preeclampsia cannot be related to a single cause and its underlying mechanism is still not clearly understood. But recent hypothesis regarding the cause of preeclampsia is more focused on the inadequate trophoblast invasion and placentation. ${ }^{6}$ Placentation error (i.e., abnormal placentation and placental dysfunction) is a key role in the development of this disorder. ${ }^{2,8}$ In our opinion, the early stages of pathogenesis of preeclampsia are placental insufficiency due to hypoxia and oxidative stress, thereby increasing apoptosis and necrosis. Thus, in addition to apoptosis, other mechanisms may be associated with this condition in preeclampsia, namely autophagy. ${ }^{2}$

The founding of autophagy in the function of human placenta only happened recently, and thus leaving the relationship between the increase of autophagy in preeclampsia in question, since it is also stated by other research that there is no increase of autophagy in cases of preeclampsia. ${ }^{5}$ An escalation in autophagic activity could be caused by the increasing oxidative stress, and it affects the trophoblast invasion and placental vasculature. When excessive autophagic activity happens, it may lead to the development of preeclampsia. In preeclampsia patients, autophagy has an important role in trophoblast function under physiologically low oxygen conditions. . $^{6,10}$

During normal pregnancy, integrin $\alpha 1 \beta 1$ (a known receptor for collagen 1, collagen IV, and also laminin) is expressed by the invasive extravillous trophoblasts (EVT). Meanwhile in pregnancy with preeclampsia, an impairment of EVT invasion occurred. The indigent EVT invasiveness and inadequate vascular remodeling has been thought to be the outcome of poor integrin $\alpha 1 \beta 1$ expression on EVTs, NK cell dysfunction, and the activation of macrophages. Hence yielding in the induction of EVT apoptosis and tumor growth factor (TGF)- $\beta$ production by hypoxic stress. ${ }^{11}$

As autophagy is a cellular bulk degradation system to sustain the cellular homeostasis under stress, it might clarify the mechanism of EVT invasion to the myometrium and maternal spiral arteries. It replaces the endothelial cells at low oxygen concentration and under stressful conditions. ${ }^{4}$ Autophagy provides energy so the cells can withstand a starvation by the degradation of cellular components. When the nutrition is sufficient, the amino acids, glucose and insulin would activate the mechanistic target of rapamycin complex 1 (mTORC1), which result in the regulation of autophagy. ${ }^{11}$

Autophagy was found in primarily cultured trophoblasts under hypoxic conditions or hypoxia-reoxygenation, mainly observed in syncytiotrophoblasts. ${ }^{12}$ Hypoxia is known to be able to promote autophagy in placental chorionic plate-derived mesenchymal stem cells, too. In fetal growth restriction (FGR) and preeclampsia, it was observed that the autophagy process in placenta was increasing. Autophagy has been observed to localize predominantly in syncytiotrophoblasts in 
most FGR cases.

Some findings suggested that autophagy is activated as a survival mechanism during nutrient deprivation. ${ }^{11}$ In complex mechanism of preeclampsia in which invasive from EVT occured, then accompanied by an increase in oxidative stress and the occurrence of hypoxia that lead to an increase in the autophagic process, it is important to observe Atg as a marker to see activity from autophagy. Seeing the activity of autophagy can provide an illustration of the severity or development of preeclampsia.

\section{Roles of Atg Proteins in Preeclampsia}

The activation of autophagy was shown by the different level of abundance of key protein of the Atg pathway. Some Atg proteins known to be related to preeclampsia are explained below.

\section{Beclin-1}

Beclin-1, which is also identified as Atg6, is a key regulator of autophagy. It was found to be a binding partner for B-cell lymphoma 2 (Bcl-2). ${ }^{13}$ Beclin-1 takes part in the initial stage of autophagy, to boost the nucleation of autophagic vesicle and recruits protein from cytosol. The expression of Beclin-1 is confirmed to be found in human placentas. However, a study showed that there is no different expression level between women with normal pregnancy and women with severe preeclampsia, ${ }^{2}$ meanwhile another study found that the expression of Beclin-1 was significantly increased in trophoblast and endothelial cells in the placenta of preeclampsia patient compared to normal. ${ }^{10}$ Although Beclin-1 is proposed to be inducing autophagy, it is still debated whether its expression increases the autophagic response.

The increased of autophagy activity has been detected in the placentas of preeclamptic patients, also it has been observed that the activity has been proved in the first trimester of pregnancy. Previous study has examined whether the presence of autophagic vacuoles can be monitored through Beclin-1 level in the first three month of placental villi trophoblast layer. The result showed that increased Beclin-1 immunofluorescence level indicates the escalating autophagy activity in cytotrophoblast cells than the syncytiotrophoblast layer in first three months of placental villi. This study proposes that ongoing autophagy happened in the cytotrophoblasts of human first three months of placental villi. ${ }^{14}$

\section{$L C 3$}

The first protein that is identified from the autophagosome membrane is LC3 protein. ${ }^{2}$ LC3 or microtubule-associated protein light chain 3 is a ubiquitin-like protein that becomes lipidated. It is a yeast Atg8 mammalian homolog protein. ${ }^{15,16} \mathrm{LC} 3$ is essential for final autophagosome formation. ${ }^{14,16}$ It is distributed ubiquitously in mammalian tissues. ${ }^{5}$

Currently, there are three isoforms of LC3 mRNA, i.e., LC3A, LC3B, and LC3C. ${ }^{2}$ After synthesis, there are two forms of LC3, namely LC3-I which is a cytosolic form, and LC3-II, a lipid phosphatidylethanolamine-conjugated form. ${ }^{14}$ LC3 proteins form LC3-I by specifically cleaved at their carboxyl terminal. Conjugation of an exposed LC3-I carboxy-terminal glycine with phosphatidylethanolamine will form LC3-II. LC3-II will serve as an autophagic marker protein because it is tightly bound to the autophagosomal membranes. ${ }^{15}$

LC3 is a protein which is most widely used to monitor the autophagy-related. To monitor completed autophagosome, LC3-II is the only reliable protein marker. ${ }^{5}$ The expression of LC3B mRNA in preeclampsia subject was increased compared with normal pregnancies. The level of LC3-II expression also increase in the patient with preeclampsia. ${ }^{2,5}$ It indicates the increase of autophagic activity. ${ }^{2}$

p62

The activation of autophagy may be reflected 
by an increase in abundance of key proteins of the pathway involved in autophagy, such as Beclin-1, protein microtubule-associated 1A/ chain 1B-light 3 (LC3), and also protein p62. Protein p62, which is called sequestosome 1 , is an intracellular adapter protein which binds intracellular component that serves to remove autophagy, p62 itself degraded by autophagy and accumulated when the autophagy was inhibited. ${ }^{5,17}$ p62 can be used as a marker to identify the autophagic flux. ${ }^{5}$ The concentration of p62 in the cytoplasm is inversely proportional to the level of autophagy induction (high p62 = low autophagy). ${ }^{17,18}$ In pregnant women with preeclampsia or hypertension disorder (gestational hypertension), significantly lowering the $\mathrm{p} 62$ value is inversely proportional to the LC3-II. This suggests that autophagy is active in placental disorders hypertension with or without FGR. ${ }^{5}$

In macroautophagy sometimes very obvious selectively ubiquitinated protein that is associated with p62, p62 works as LC3-II protein to trap longevity to autophagosomes. In p62 accumulation that indicates a lack of autophagy, p62 activates nuclear factor $\kappa \mathrm{B}$ (NF-kB) pathway, which leads to suppression oxidative stress, in addition, the build-up of p62 activates nuclear factor-erythroid 2-related factor 2 (NRF-2) and antioxidant gene targets. ${ }^{18}$ The obtained expression of $\mathrm{p} 62$ from woman with preeclampsia in their third-trimester may represent the inhibitory factors found in the circulation, which are quantitatively different from the elevated level of oxidative stress presents in placenta at the early stages of preeclampsia. ${ }^{17}$

\section{Conclusion}

In preeclampsia patients, autophagy has an important role in trophoblast function under physiologically low oxygen conditions, since trophoblast invasion is influenced by the increase of oxidative stress. Increased autophagy in the placenta was also found in FGR and preeclampsia. The activation of autophagy in preeclampsia is shown by the different level of abundance of key protein of the Atg pathway. Some Atg proteins known to be related to preeclampsia are Beclin-1, LC3, and p62. Beclin-1 is proposed to be inducing autophagy, its positivity suggested to reflect the increased autophagy level in cytotrophoblast cells in first trimester placental villi. The level of LC3-II expression also increase in the patient with preeclampsia, indicating the increase of autophagy activity. In pregnant women with preeclampsia or hypertension disorder, p62 value is significantly lower.

\section{Acknowledgement}

We thank Dr. Anna Meilana, M.Kes, Apt. for the assistance in writing this article.

\section{Funding}

The study was not funded by any source of grants.

\section{Conflict of Interest}

The authors declared no potential conflicts of interest with respect to the study, authorship, and/or publication of this article.

\section{References}

1. Tsujimoto Y, Shimizu S. Another way to die: Autophagic programmed cell death. Cell Death Differ. 2005;12:1528-34. doi: 10.1038/sj.cdd.4401777

2. Oh SY, Choi SJ, Kyung Hee Kim, Cho E, Kim JH, Roh CR. Autophagy-related proteins, LC3 and Beclin-1, in placentas from pregnancies complicated by preeclampsia. Reprod Sci. 2008;15(9): 912 -20. doi: 10.1177/1933719108319159

3. Thorburn A. Apoptosis and autophagy: 
Regulatory connections between two supposedly different processes. Apoptosis. 2008;13(1):1-9. doi: 10.1007/s10495-007 $-0154-9$

4. Mizushima N, Levine B. Autophagy in mammalian development and differentiation. Nat Cell Biol. 2010;12(9): 823-30. doi: 10. 1038/ncb0910-823

5. Akaishi R, Yamada T, Nakabayashi K, Nishihara H, Furuta I, Kojima T, et al. Autophagy in the placenta of women with hypertensive disorders in pregnancy. Placenta. 2014;35(12):974-80. doi: 10.10 16/j.placenta.2014.10.009

6. Nakashima A, Yamanaka-Tatematsu M, Fujita N, Koizumi K, Shima T, Yoshida $\mathrm{T}$, et al. Impaired autophagy by soluble endoglin, under physiological hypoxia in early pregnant period, is involved in poor placentation in preeclampsia. Autophagy. 2013;9(3):303-16. doi: 10.4161/auto.229 27

7. Gong JS, Kim GJ. The role of autophagy in the placenta as a regulator of cell death. Clin Exp Reprod Med. 2014;41(3):97-107. doi: 10.5653/cerm.2014.41.3.97

8. Varija T, Vanaja D, Sindhura S, Raghavenda B. A study of prevalence and association of fundus changes in pregnancy induced hypertension. Int $\mathrm{J}$ Reprod Contracept Obstet Gynecol. 2016; 1375-9. doi: 10.18203/2320-1770.ijrcog2 0161289

9. Yusrawati Y, Habibah RL, Machmud R. Differences in maternal leptin serum levels between normal pregnancy and preeclampsia. Indones Biomed J. 2015;7 (1):37-42. doi: 10.18585/inabj.v7i1.20

10. Gao L, Qi HB, Kc K, Zhang XM, Zhang $\mathrm{H}$, Baker PN. Excessive autophagy induces the failure of trophoblast invasion and vasculature: Possible relevance to the pathogenesis of preeclampsia. J Hypertens. 2015;33(1):106-17. doi: 10.1097/HJH.00

\section{6}

11. Saito S, Nakashima A. A review of the mechanism for poor placentation in earlyonset preeclampsia: The role of autophagy in trophoblast invasion and vascular remodeling. J Reprod Immunol. 2014;101 -102:80-8. doi: 10.1016/j.jri.2013.06.002

12. Chen B, Longtine MS, Nelson DM. Hypoxia induces autophagy in primary human trophoblasts. Endocrinology. 2012; 153(10):4946-54. doi: 10.1210/en.20121472

13. Bildirici I, Longtine MS, Chen B, Nelson DM. Survival by self-destruction: A role for autophagy in the placenta?. Placenta. 2012;33(8):591-8. doi: 10.1016/j.placent a.2012.04.011

14. Chifenti B, Locci MT, Lazzeri G, Guagnozzi M, Dinucci D, Chiellini F, et al. Autophagy-related protein LC3 and Beclin-1 in the first trimester of pregnancy. Clin Exp Reprod Med. 2013;40(1):33-7. doi: 10.5653/cerm.2013.40.1.33

15. Hansen TE, Johansen T. Following autophagy step by step. BMC Biol. 2011; 9(1):39. doi: 10.1186/1741-7007-9-39

16. Avagliano L, Virgili E, Garò C, Quadrelli F, Doi P, Samaja M, et al. Autophagy and human parturition: Evaluation of LC3 expression in placenta from spontaneous or medically induced onset of labor. BioMed Res Int. 2013;2013:1-9. doi: 10. 1155/2013/689768

17. Kanninen T, Jayaram A, Jaffe Lifshitz S, Witkin S. Altered autophagy induction by sera from pregnant women with preeclampsia: A case-control study. BJOG Int J Obstet Gynaecol. 2014;121(8):95864. doi: 10.1111/1471-0528.12755

18. Wu F, Tian F-J, Lin Y. Oxidative stress in placenta: Health and diseases. BioMed Res Int. 2015;2015:1-15. doi: 10.1155/20 $15 / 293271$

(C) 2020 Dewi et al. The full terms of this license incorporate the Creative Common Attribution-Non Commercial License (https://creative commons.org/licenses/by-nc/4.0/). By accessing the work you hereby accept the terms. Non-commercial use of the work are permitted without any further permission, provided the work is properly attributed. 